\title{
YOSHIMASU Todo's Philosophy of Medicine : In Comparison with that in Ancient China
}

\author{
Masami TATENO \\ Nihon University, College of Humanities and Sciences, 3-25-40 Sakurajyosui, Setagaya-ku, Tokyo 156-8550, Japan
}

吉益東洞の医学思想一中国古代医学思想との対比において

舘野 正美

日本大学文理学部中国語中国文化学科，東京， $=156-8550$ 世田谷区桜上水3-25-40

\begin{abstract}
YOSHIMASU Todo is one of the greatest practitioners of so called Koiho in the Edo era Japan. There have hardly been any studies, however, on his philosophy of medicine, even though it seems to be a significant background for his medical practice. Accordingly, I would like to consider Todo's philosophy of medicine called manbyo-ichidoku-setsu in comparison with that of Chinese.

I first take up the Chin-shu chapter of the Lu-shi chun-chiu, which he recognized as the source of his theory, to see the philosophy of medicine of cosmic order, the "holistic total". Then I'll take the other classics of traditional Chinese medicine to clarify their characteristics. Hitherto there has been lack of comparative exploration on Todo's notion with that of Chinese from the view point of philosophy of medicine.

In comparison with that traditional Chinese medicine, we can assert that Todo learned traditional Chinese medicine with its philosophical background, and created further Japan's own characteristic Kampo medicine. Seeing respectively on these two points that are his analysis on each galenical, and his administrations of intensive drugs to reduce "poison" under his manbyo-ichidoku-setsu, we can assert that Todo really is one of the "fathers of Kampo medicine".
\end{abstract}

Key words: YOSHIMASU Todo, manbyo-ichidoku-setsu (Pathology of thousands of diseases from one toxin), the Lu-shi chun-chiu

\section{要旨}

吉益東洞，我が国江戸時代における，所謂 “古医方”最大の医家であるが，彼の医学思想については，未だ論究 の及んでいない点もあるように思われる。そこでこの東洞の医学思想について, 中国古代の医学に鑑み, その万病 一毒説を中心に考えてゆきたい。

そこで先ず, 東洞がその万病一毒説の淵源としている『呂氏春秋』「尽数篇」を取り上げ, そこにおける中国医学 の基本的な考え方, 即ち天地一体の思想を垣間見て, 更にそれをその他の中国医学古典において概観してゆく。こ のような医学思想的観点からの中国医学との対比が，従来の東洞研究に欠けていたのである。

その結果, 東洞がそれらを吸収しその根底に置きつつ, 更に弛まぬ医学的実践に基づいて, 独自の“漢方医学” を樹立したことが分かる。即ち, 彼は中国医学の伝統を守りつつ, 敢えて峻剤を用いて病毒を去る, という臨床的 姿勢を貫き, かつ生薬 つつつの薬効の分析に意を注いだのである。彼こそ正に“日本漢方の父”の1人であると 言えるであろう。

キーワード : 吉益東洞, 万病一毒説,『呂氏春秋』

\section{Introduction}

YOSHIMASU Todo [吉益東洞] (1702-1773) was one of the greatest medical practitioners in the Koiho [古医方］ school in the Edo [江戸］ era Japan. As is asserted in general that he denying yin-yo go-gyo［陰陽五行］ theory, and asserting a fatalism peculiar to him, espoused poison like intensive drugs for those with fatal diseases to administer.
There have been a lot of studies on his medical practices from the viewpoint of medical science and pharmacology $y^{1)}$.

There have hardly been any studies, however, on his philosophy of medicine compared with that of Chinese, even though his philosophy of medicine, which is exclusively his own one, even brought about under some influences from that of Chinese, 
seems to be a significant background for his medical practice.

The reason why there have hardly been any precise researches on his theoretical formulations apparently is that there is a lethal lack of a view point of medical philosophy as ever. Hitherto there has been lack of comparative exploration on Todo's notion with that of Chinese from the view point of philosophy of medicine.

\section{Method and Materials}

As is above, accordingly, I would like to consider Todo's philosophy of medicine called manbyoichidoku-setsu [万病一毒説] through a study of his criticism of the yin-yo go-gyo [陰陽五行] theory so that we may clarify his true will in his remedy based on his philosophy of medicine.

In this article, I first take up the very first characterization of the philosophy of traditional Chinese medicine, which we can find in the Chin-shu chapter [尽数篇] of the Lu-shi chun-chiu [呂氏春秋], since it describes the core modality of the philosophy of medicine, and is actually back-grounded by a common conception of cosmic order, the "holistic total", that is, a world view that takes the world synthetically as a whole, and emphasizes the importance of achieving a good balance of constituents (= cosmic harmony) of the whole world in order to achieve a healthy life and longevity. And additionally, this is the description of what Todo embodied himself but he could not deliver it on the verbal level of cognition.

Chinese philosophy of medicine, which has been based on "synthesis", and the basic characterization of which is found in the Chin-shu chapter of the $\mathrm{Lu}$ shi chun-chiu, conveys to us a basic notion of that. For this reason, after a general survey of the contents in the Lu-shi chun-chiu, in order to understand this notion, I consider some other "classics" of Chinese medicine, which seem to be the heirs of it. Then, I look into Todo's philosophy of medicine referring to his medical practices. Based on the above observations, I will make the following assertions about Todo's and additionally Japanese Kampo's features :

1) The core worldview found in the Chin-shu chapter of the Lu-shi chun-chiu is the notion of the "holistic total," derived from the intrinsic mode of scientific thought, "synthesis," where we, humanbeings, exist in psycho-somatic harmony in the cosmic order-cosmic harmony.

2) Those notions are actually conveyed in the heirs of traditional Chinese medicine like the Huangting nei-ching and the other works on traditional Chinese medicine.

3) When they were transported into Japan, they were naturally accepted into the Japanese mind, even though there was some "dyspepsia." Nevertheless, there still seems to be some typical Japanese characteristics in the process of transmission, such as "conformity," more precisely "import and create". And its typical phase is come across in YOSHIMASU Todo's medical practices based on his philosophy of medicine.

To begin with, I will take up the Chin-shu chapter of the Lu-shi chun-chiu to clarify the notion of a "holistic total" as the core cosmic order of the philosophy of medicine, which are common in ancient China and in Todo, Japan.

\section{Results}

\section{The Chin-shu chapter of the Lu-shi chun-chiu}

We can find the paragraph which describes the first form of the ancient Chinese philosophy of medicine, which would seem to be much more theoretically described in the Huang-ting nei-ching [黄 帝内経] and the other volumes down through the ages are found in chapter 3-2 of the Lu-shi chunchiu, the Chin-shu chapter, the chapter regarding the achievement of a longevity. Namely, the original modality of the ancient Chinese philosophy of medicine, which is later called "Nei-ching i-hsueh" [内 経医学], are all lined up here in the Chin-shu chapter of the Lu-shi chun-chiu, as follows :

Tien [天], Heaven, as a metaphorical expression of Mother Nature, created the diverse modalities of phenomenal conditions in the daily world such as sunny-shady, cold-hot and desiccation-humidity. The four seasons are turning, and "the everything" is changing, doing both benefit and harm to our lives. The sage, discerning the facilities of the phenomenal conditions above and disclosing the profit in "the every-thing", will accord with every facility of his life. In this manner, his mind would rest peacefully in his body, and he would have a long life ${ }^{2)}$.

The passage can be understood as follows : the sage will work for the cosmic harmony of mind and body to achieve long life according to the diverse modalities of the phenomenal conditions in the world of nature (such as sunny-shady, hot-cold, four seasons, and so forth) that Heaven has created. In 
this paragraph, we can grasp the typical expression of the cosmic harmony of a holistic total in Chinese philosophy of medicine that is intrinsically based on the cosmic order derived from the modality of synthesis. The first point to notice is that they regarded Tien, which entails the cosmic harmony of the phenomenal diversities derived from "synthesis", as a symbolization of the cosmic order, and according to this "order" a human being in the physiological level would be inherently long-lived.

This striking, but at the same time natural, view of the nature of longevity would be seen as universal, at least in the context of philosophy of medicine in ancient times. That is to say, this view is one of the most crucial in the philosophy of medicine of classical times just as was the conception of vis medicatrix naturae $e^{3)}$. This view seems so crucial that it should even be reconsidered now along with the philosophical background, since the modern and highly developed medicine seems to have been developed through the process of "forgetting" this view. This is an irony of philosophy.

In fact, this view of our nature, which describes a human being as an integration of mind and body, is the crucial key to the longevity, and this is enumerated as one of the core features of the cosmic order of Tien in the ancient Chinese philosophy of medicine. Todo also took his view on it almost instinctively. However, he did not take it indiscriminately. He criticized it precisely and even practically.

A mere homo sapience broken down to a collection of cells in compliance with Vilchow's cellularpathology in the modern theoretical formulation of medicine could not be designated a true human being of our everyday experience. We can find large numbers of patients with unrelievable distress who are exhaustively analyzed as a mere diseased objects. We, human beings, live in the harmony of bodies and minds - the cosmic harmony. We are not just objects but living creatures with body and mind. The early Chinese philosophers of medicine understood this clearly.

The Chin-shu chapter continues :

Longevity is not merely a collection of short lives, but is an accomplishment of one's life. In order to achieve longevity, one should avert harm. How can one do it? Too much sweet, too much sour, too much bitter, too much hot, and too much salty, when one's body is filled with any one of these five "too much tastes", it brings harm. Too much joy, too much anger, too much anxiety, too much fear, and too much grief, when any one of these five "too much feelings" get in one's mind, it brings harm. Too much cold, too much hot, too much desiccation, too much humidity, too much wind, too much rain, and too much fog, when any one of these seven "too much weather" move in on one's spirit, it brings harm ${ }^{4}$.

This passage suggests a concrete strategy for caring for life and achieving longevity based on the fundamental world view alluded to above- the cosmic harmony of a holistic total based on the cosmic order $^{5}$. Namely, in order for a human being to be long lived, it is indispensable that :

1) One should avoid "too much tastes", that is, an unbalanced diet with too much sweet, too much sour, and so on. That is to say, one should keep temperate tastes.

2) One should refrain from too much trembling in his mind, such as too much joy, too much anger, and so on in his daily life.

3) One should accommodate oneself to the weather.

Even though human beings are disposed to be long lived by nature, numerous "too much"get in the way of our longevity. These "too much" cause harm, hai [害], to the cosmic harmony of a holistic total, and distance people from the cosmic order causing them to fall ill.

This passage advocates 1) temperate tastes for one's body, 2) control over one's emotions, and 3) enabling various changes of the environment to get in one's spirit, ching [精], as will be shown later. It is an assertion of temperance in daily life. It is one of the most typical features of the cosmic order reflected in the Chinese philosophy of medicine in ancient times. In fact, an even more crucial aspect of this description is that human diseases, hai, have been understood pathologically in the holistic totality of an ontological level of human being - body, mind and mind-body. It is not a product of "analysis", but only "synthesis" can entail such pathological formulation. This is one of the greatest features of the ancient Chinese philosophy of medicine.

Regarding this point, the Chin-shu chapter elaborates :

When the vital forces, ching-chi [精気], gather, they necessarily make some things. Gathering in a bird, they will make it fly in the sky ; gathering in an animal, they will make it move in the field; gathering in a gem, they will make it glitter; 
gathering in a tree, they will make it rampant; and gathering in a sage, they will make him bright $^{6}$.

The vital forces, ching-chi, in this passage are the essential being of things on the epistemological level. There are numerous points that could be made on this issue. However the only philosophically significant point to be taken in this passage is that the vital forces of ching-chi are supposed to compose both the body and mind of human beings just as they construct birds, animals, gems, and so forth. Not only our body but also our minds are composed of the vital forces of ching-chi.

From a philosophical point of view, what the vital forces, ching-chi, scientifically are, or how we can see them through some artificial mechanisms, is not such a crucial point. Rather, this world view, in which our body and mind, even the whole world itself, are taken to be one "holistic total" on the same ontological level, is the point of which we should take special note in this paper. We, human beings, are living in the cosmic harmony of body, mind, and the whole world as one holistic total.

It is precisely on this philosophical basis of the cosmic order that a human being is to be grasped as an existence of the holistic total of body and mind, and at the same time a human being, and the whole universe is conceived as one in the cosmic harmony, not just as a theoretical formulation but in reality. In one word, the vital forces, ching-chi, are the fundamental essence of the mind-body, and of human beings and the universe linked together both on the epistemological and the ontological level. In other words, the vital forces, ching-chi are not just a conception of mediation among them but a mediation itself to compose the cosmic order of a holistic total of the cosmic harmony.

Furthermore, on the metaphysical level, the philosophically crucial point here is that this basic idea of the holistic total of body and mind, later known as shen-hsin i-ju [身心一如], in the ancient Chinese philosophy of medicine is intrinsically back-grounded by some profound philosophy like Lao-tzu's Tao. Though Lao-tzu did not adopt the vocabulary shen-hsin i-ju, I could manifestly find his philosophical praxes through respiratory control which he described as to "make abdomen" (Lao-tzu, 12) i.e. to do abdominal breath to integrate mind and body. I have discussed this in more detail elsewhere in my paper before ${ }^{7)}$. Suffice it to say here that the ancient Chinese philosophy of medicine is not just about fitness or health care but has a profound back- ground.

We are now in a position to assert that the philosophy of medicine we find in the Chin-shu chapter of the Lu-shi chun-chiu furnishes us with the typical formulations of the cosmic harmony that is the holistic total of mind and body and, further, human beings and the whole universe under the great cosmic order of Tien on which Todo based and developed his own-Japan's own-Kampo medicine.

Now I would like to take a step forward to the Huang-ting nei-ching and the other works on traditional Chinese medicine to clarify how they inherited and extended the convention hereinafter.

\section{The Huang-ting nei-ching, and the other works on traditional Chinese medicine}

The Huang-ting nei-ching is the first set of volumes with the complete theoretical formulations of traditional Chinese medicine in the Chinese history of medicine. The current volume of Huang-ting neiching principally consists of two sections, Su-wen [素問] and Ling-shu [霊枢], both of which can be said to have been compiled around the time of the Han dynasty. Su-wen chiefly discusses pathological formulations and Ling-shu describes acupuncture.

It goes without saying that there should be really a lot of interesting topics from various points of views, but the point to be taken in this paper is that the fundamental modality running through each of the theoretical formulations in this classic is the yinyang wu-hsing [陰陽五行] theory. The theory is the most conventional expression of the Chinese mode of thinking which has the same origin of cosmic order that we have seen in the Lu-shi chun-chiu derived from the concept of Tien. Accordingly, we can assert that the cosmic order represented by the concept of ching-chi in the Lu-shi chun-chiu has been developed to be the yin-yang wu-hsing theory in the Huang-ting nei-ching remaining intrinsically and semantically in the same mode.

Furthermore, more precisely, we can grasp the same but developed phraseology of the cosmic harmony as a holistic total in many passages of this volume. Actually they regarded our body, bodymind, and body-mind and the whole world to be one as a holistic total in the cosmic order and our healthy lives are accomplished by the cosmic harmony under the same order.

For example,

In the ancient times, a person who attained the Tao would follow yin-yang, accord with the way, keep moderate in foods and drinks, lead regular 
life and not work recklessly. Therefore, he could harmonize body and mind, achieve his longevity derived from Tien, and so pass away over one hundred years old ${ }^{8}$.

In this passage, the cosmic order we saw in the Lu-shi chun-chiu is described typically through the new concept of yin-yang. As we see, it is just the same notion about our longevity which was delineated in the Lu-shi chun-chiu, that is the longevity through the cosmic harmony of holistic total. And this idea is theoretically formulated further through the epistemological scheme of yin-yang wu-hsing in those chapters of this classic as wu yun hsing ta lun [五運行大論], liu yuan cheng chi ta lun [六元正 紀大論], etc., which is so called a pathological theory of “wu-yun [五運]" that is yun-tung [運動] (= movement) of wu-hsing [五行].

Accordingly, it seems a quite natural result that this cosmic harmony, derived from the cosmic order formulated through the concept of yin-yang would yield such a clinical theory as follows :

A good acupuncturist would draw yang out of yin and yin out of yang, treat left by right and right by left, understand that by this and back by front, and he would grasp the reason of surplus and shortage, and see the subtle symptoms to know the diseases, then there would be no problem ${ }^{9}$.

Too much yin harms yang, and too much yang harms $\operatorname{yin}^{10}$.

The above passages assert that the proper balance of yin-yang, i.e. the cosmic harmony of holistic total, is the crucial condition for a healthy life and longevity, and imbalance and lack of harmony lead us to disease, therefore the main clinical procedure is "harmonizing" of yin-yang wu-hsing in order to prevent diseases which is typically delineated as :

\section{A good practitioner prevent diseases ${ }^{11)}$.}

This idea is obviously the inheritance of "cosmic harmony" which we can find in the Lu-shi chunchiu.

Now we will consider another classic of traditional Chinese medicine, that is the Shang-han-lun [傷寒論]. The Shang-han-lun is the oldest classic for the remedy of acute febrile infections in traditional Chinese medicine. This classic is said to be originally compiled in the third century, around the end of the later Han dynasty, as a comprehensive survey of Chang-chung-ching's [張仲景] pharmaceutics. It has been handed down to be printed and published in the tenth century, during the Song [宋] dynasty. Now, leaving aside all the questions of philology regarding this classic, I would like to point out the philosophical modality of the pharmaceutical theory of san-yin san-yang [三陰三陽] is the same old cosmic order of holistic total we saw in the Lu-shi chun-chiu. To put it in another way, the cosmic harmony of holistic total derived from Tien which has been found originally in the Lu-shi chunchiu is also expressed in the theoretical formulation of pharmaceutics in this book.

In this classic, human diseases, especially acute febrile infections, are identified in six stages, of three-yin and three-yang. They are: tai-yang [太 陽， yang-ming [陽明], shao-yang [少陽], tai-yin [太陰], shao-yin [少陰], and chueh-yin [厥陰], and are treated according to each phase of the six stages through the most appropriate formulae, e.g. in general, for the yang stages (tai-yang, yang-ming, and shao-yang) han-chi [寒剂] (cool efficacious formulae) like gui-chi-tang [桂枝湯], ke-ken-tang [葛根湯］ etc. should be taken, on the other hand, for the ying stages (tai-yin, shao-yin, and chueh-yin) wen-chi [温剤] (warm efficacious formulae) like ssu-ni-tang [四逆湯], chen-wu-tang [真武湯] etc. should be administered.

This traditional Chinese pharmacological theory is actually formulating the cosmic harmony of holistic total, which is typically articulated as : cool efficacious formulae for the warm stages and warm efficacious formulae for the cool stages. At this point, we can see the typical example of the cosmic order contained in this volume, which we have already seen in the Chin-shu chapter of the Lu-shi chun-chiu above.

As a parenthetical remark, I would point out the crucial modality of Chang's pharmaceutics-"synthesis", namely his 117 ways of pharmaceutics in this book is nothing but the "combinations" of 72 kinds of singular galenical without any "analysis". Chang just synthetically combined various galenicals for each phase or stage of disease under the cosmic harmony of holistic total. He was another resident under the cosmic order of Tien. On the contrary, Todo took another way of "analyses" we will see below.

Now I would take another look at the Shen-neng pen-tsao ching [神農本草経]. In this classic of traditional Chinese medicine, especially galenicals, those galenicals, even though they are divided into three levels, upper, middle, and lower, yet are not 
analyzed in their component level like Theophrastus or Dioscorides in ancient Greece.

They synthetically arranged/composed those galenicals into efficient pharmaceutics accoding to the chi-ching [七情] theory. What is called "chiching" literally means "seven conditions" (of employment of the galenicals), e.g. tuan-hsing [単行] (single use), hsiang-shu [相須] (efficient reinforcement), hsiang-sha [相殺] (toxicity offset), etc. They made various combinations of each single galenical in accordance with the efficiencies for each phase of diseases. This best fitted cosmic harmony of pharmaceutical formula is one of the typical manifestations of the cosmic order of Tien derived from the intellectual modality of synthesis, which we saw in the Lu-shi chun-chiu earlier. We can see the same cosmic order here in this classic again. It seems reasonable to say that this traditional cosmic order has been inherited as an intrinsic principle in the field of Chinese traditional medicine for centuries which evidently entails an inheritance of "to prevent disesases".

What is further noteworthy in this point is the upper level drugs are, in point of fact not "drugs" nowadays but health food for everyday life without any toxic side effects to prevent diseases, and the lower ones are what we call nowadays "drugs" to cure diseases with some toxic side effects. They regarded what we call "drugs" as "lower", inferior ones, but Todo used to administer them for his patients. He was really a harbinger of us.

\section{YOSHIMASU Todo's philosophy of medicine}

In the studies of Todo's philosophy of medicine, hitherto, it is generally accepted that he was quite emphatic in denying the theory of yin-yo go-gyo. He writes :

We should not talk about human affairs in accordance with the theory of yin-yo go-gyo. But now, such talk has become fashionable, and the true way (of medicine) went out of use. $\cdots \cdot$. Alas ! $!^{12}$

We can see the theory of yin-yo go-gyo in the $\mathrm{Yu}$-shu [盧書] and Hung-fan [洪範］ chapters. …..However, they are merely the words of the theoretical formulations. If adopted to our pharmaceutics, it would bring about wrong results. This is why we do not take $\mathrm{it}^{13)}$.

Looking into Todo's descriptions much more precisely once again, however, we can see that he does not reject the theory of yin-yo go-gyo thoroughly.
As he proclaims :

Well, yin-yo is a matter of nature ; not human society ${ }^{14}$.

Now, genki [元気] is one fundamental ki of yinyo from Heaven. Human beings are brought forth in it. This is a ki a-priori ${ }^{15)}$.

Todo never denies the existence of the ki of yinyo itself. He just refuses to apply the yin-yo, more precisely the theory of yin-yo, to his daily clinical practice. He was actually thinking in terms of that old cosmic order derived from Tien in ancient China. So if asked whether Todo really denied and rejected the theory of yin-yo go-gyo, then the answer is definitely "No". He didn't deny it nor reject it, but he didn't include it in his theoretical formulations.

Namely, first he clearly defines the distinction between theory and practice, offering the following explanation :

According to an ancient saying: Just taking a good rest, when you are ill, is equal to seeing an ordinary doctor. Isoku [為則] $(=$ Todo = I) would say: When I found this ancient saying for the first time, I was so ashamed of myself as a medical doctor. $\cdots \cdot$... As we can see the doctors who rely upon the theory of yin-yo do not obtain good results, I understand that these words are not irrelevant. $\cdots \cdots$. Then I studied hard every day and night, and at last I became versed in the core point of the healing arts- the Tao of medicine, Ido [医道] - then I felt exempted from the censure of those ancient words. …... My apprentices, be discreet yourselves. Do not be deluded with medical theory or its technical terms. Even though you should read all of the books of medical technologies and memorize the technical terms, if you can not cure people of their diseases, then you can not be exempted from the censure of those words ${ }^{16)}$.

We can see clearly that Todo's main purpose is to practice his healing arts to cure peoples' diseases and not to make theoretical descriptions of medical techniques or symptoms through the theory of yinyo go-gyo, which he believed might sometimes even be harmful to patients.

In other words, Todo seems to have an intense conviction that each medical practitioner must study and train in one's own practice of healing arts, and it is not the main job to formulate medical descriptions 
theoretically in the context of the theory of yin-yo go-gyo, so he criticized sternly those who adhered to the theory itself yet were not effective at curing diseases.

Here we see clearly that Todo almost unconsciously adopted that old cosmic order in his intellectual modality, but at the same time he didn't take the theory of yin-yo go-gyo as it is, he devised his own theoretical formulations.

And then, he devised manbyo-ichidoku-setsu, a medical theory that explains every phase of various diseases through one concept of "doku" [毒], poison, as a descriptive formation of his expressions of his philosophy of medicine, he writes :

A master of healing arts does not rely upon medical examinations, but can just see the place where the poison of diseases, byodoku [病毒] is ${ }^{17}$.

Medical doctors in an orthodox school would take manbyo-ichidoku-setsu, and remove the poison from the patients through perspiration, emesis, and excretion, then diseases and symptoms would all disappear ${ }^{18)}$.

As I see it, Todo really was a master of healing arts who embodied the Tao of medicine, I-do, through his clinical training of healing arts and applied it to his biomedical practice. Holding firmly to the cosmic order of Chinese origin, Todo asserts his view on clinical praxis through his own words as well. This is a typical status of Japanese scheme of "import and create". We can see it everywhere in Todo's works now.

Now, leaving aside precise analyses on Todo's philosophical theory of medicine, what should we learn from Todo's philosophy of medicine concerning our focus? That would be a well digested Japanese style cosmic order which is really in the Japanese style though it derived from that old cosmic order in ancient China.

As for Todo, he clearly did not attach importance to knowledge-base clinical techniques, at least he strictly distinguished knowledge-base theory from the clinical techniques - in this point he is in the same traditional medical domain as that elucidated in the Chin-shu chapter of the Lu-shi chun-chiu as we saw above, but he created a new Japanese way of paradigm that actually cure the diseases through his resolute I-do. Todo's works represent a typical Japanese manifestation of the Japanese practices even under the cosmic order of Tien in ancient China, but are in fact "Japanese Kampo".

\section{Discussion}

Now we have seen a general survey of the philosophy of traditional Chinese medicine, and that of YOSHIMASU Todo's. I first took up an early characterization of the philosophy of traditional Chinese medicine, which we can find in the Chin-shu chapter of the Lu-shi chun-chiu, since it describes the core modality of the philosophy of medicine.

In the West, "analysis" is the core philosophy (e.g. cellular-pathology, DNA, "spare parts", etc.). This is in contrast with the Chinese philosophy of medicine, which has been conceived by "synthesis." However, Todo, understanding this way, took also an analytic way to galenicals, and wrote the Yakucho [薬徵]. Consequently we can elucidate that he had a notion like Western "analysis" as early as in the Edo era Japan.

On the other hand, above mentioned theories assert in the Lu-shi chun-chiu that the good balance of yin-yang, i.e. the cosmic harmony of holistic total, is the crucial condition for a healthy life and longevity, and imbalance and lack of harmony leads us to disease. Therefore the main clinical procedure is the "harmonizing" of yin-yang wu-hsing, which has been inherited and developed in the Huang-ting neiching afterward.

Todo acquired this status only by himself and was so much glad to find it in the lines in the Chin-shu chapter,the Lu-shi chun-chiu when he stumbled on his words to convey his sealed meanings. However Todo, while he understood the significance of the Lu-shi chun-chiu, he took his own way to administrate an intensive drug where it should be done under his assertion of "manbyo-ichidoku-setsu".

Then I took another classic of the classics of traditional Chinese medicine, that is the Shang-han-lun. The Shang-han-lun is the oldest classic for the remedy of acute febrile infections in traditional Chinese medicine.

This traditional Chinese pharmacological theory actually formulates the cosmic harmony of holistic total, which is typically articulated as : cool efficacious formulae for the warm stages and warm efficacious formulae for the cool stages. At this point, we can see the typical example of the cosmic order contained in this volume. Todo understanding the significance of it, then he raised a notion that not accepting it indiscriminately, but we should administer some of intensive medicine on accordance with our own prescription. We could see a typical status of the Japanese "import and create" modality in his description as a "harbinger". 


\section{Conclusion}

We have seen the characteristics of the ancient Chinese medicine, whose philosophy is described theoretically as :

1. They took human being as a holistic total of mind-body and human-universe, so we can accomplish our longevity through the custody of this cosmic harmony.

Then here are the points of their philosophy of medicine :

2. to prevent diseases e.g. the Huang-ting neiching, and the Shen-neng pen-tsao ching

3. syntheses e.g. the Shang-han-lun

Todo learning traditional Chinese medicine with its philosophical background, and created further Japan's own characteristic Kampo medicine as we have seen :

4. analysis in the Yaku-cho

5. administrations of intensive drugs under his theory of manbyo-ichidoku-setsu

So for now we can assert that Todo is one of the "fathers of Kampo medicine".

\section{Endnotes}

1) As one of the most distinctive general survey, I name $\mathrm{Yu}$ Fujikawa :『日本医学史』, (Japanese history of medicine), 96 ff, 342 ff, 352 ff, Keiseisha, Tokyo, 1972.

2 ) As I would refer to later, the Lu-shi chun-chiu is the book that Todo sited with great pleasure as the origin of his theory of manbyo-ichidoku-setsu, and at the same time, he intrinsically lived in the same context not only theoretically but also ontologically. For the further details on this matter, see my『吉益東洞『古書医言』の研究』(A study of YOSHIMASU Todo's Kosho-igen), $100 \mathrm{ff}$, Tokyo : Kyuko shoin, 2004.

The Lu-shi chun-chiu, A Concordance to the $L u$ shi
Chun-qiu, 12, The Commercial Press, Taipei, Taiwan, 1996.

All translations throughout this paper are my own.

And also, about the philosophy of medicine in the $L u$-shi chun-chiu, see my paper “由《呂氏春秋》看中國古代 身心相關醫學思想” (Philosophy of psychosomatic medicine in ancient China from the viewpoint of the $L u$-shi chun chiu), in 《中國古代思想中的氣論及身體觀》 (The theory of ch'i and views of the body in ancient Chinese philosophy), edited by R. P.Yang, Taipei, Taiwan : Chiu Liu Press, 1993, pp. 485-96

$3)$ We can also find this precious notion in Hippocrates' words (e.g. in his On Epidemics, 6) or even in the famous words of Ambroise Pare's "Je le pansay, Dieu le guarit."

4 ) op. cit., 12 .

5 ) Here, in this passage, we can see the original modality of pathogenetic idea not only of Nei-chin i-hsueh but also that of Chen-yen [陳言] in the south Song [宋] dynasty.

6 ) op. cit., p.13.

7 ) For the further details on this issue, see my "Lao-tsu's Tao and an Ancient Chinese Philosophy of Medicine: A Philosophical Background of Traditional Chinese Medicine" in Studies in Humanities and Sciences, 68, Nihon University, Tokyo, September, 2004.

8 ) Huang-ting nei-ching Su-wen, 28, Gakujyutsu shuppansha, Tokyo, 1991

9) ibid., 127.

10) ibid., 104.

11) Huang-ting nei-ching Ling-shu, 131, Hebei kexue jishu chubanshe, Shijiazhuang, 1994

12）Kosho-igen, vol. 1, in『東洞全集』(Todo's Opera), 42, Kyoto, Japan : Shibunkaku, 1970. For the further details of YOSHIMASU Todo's philosophy of medicine, see my 『吉益東洞『古書医言』の研究』(A study of YOSHIMASU Todo's Kosho-igen ), 100 ff, Tokyo : Kyuko shoin, 2004.

13) Idan, ibid., 448.

14) Kosho-igen, vol. 1, ibid., 42.

15) Idan, ibid., 445.

16) Kosho-igen, vol.4, ibid., 121.

17) Todo Sensei Tomonsho, ibid., 463.

18) Kosho-igen, vol.2, ibid., 72. 